\title{
Will mandatory audit firm rotation reduce audit market concentration in South Africa?
}

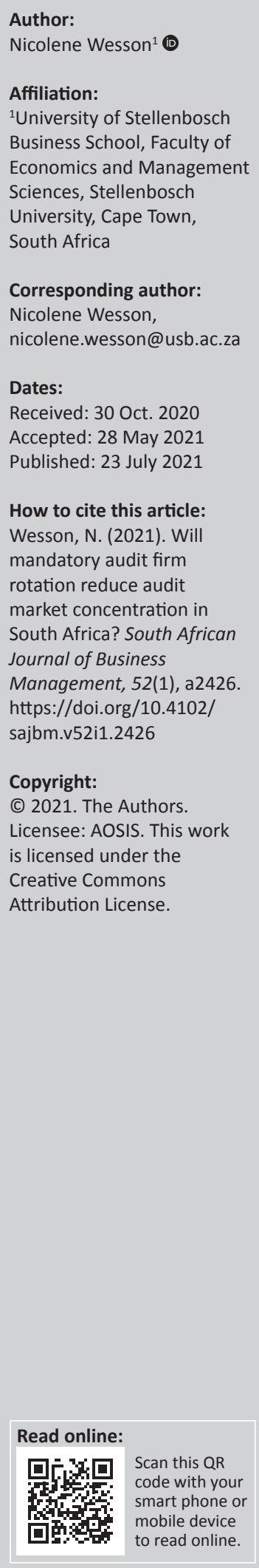

Purpose: Deconcentrating the audit market was one of the stated objectives of the proposed mandatory audit firm rotation (MAFR) ruling in South Africa. With MAFR being a contentious topic, this study aimed to explore the possible effect of MAFR on audit market concentration in South Africa in anticipation of the implementation thereof in 2023.

Design/methodology/approach: A sample of 415 South African listed companies was studied for the period 2010-2018. Data were mainly captured from annual reports. Descriptive statistics and significance testing were performed on calculated concentration ratios and identified audit firm rotations.

Findings/results: South African audit market concentration mirrored empirical evidence from most developed countries - with Big 4 audit firms dominating the audit market, whilst a monopoly within the Big 4 audit firm grouping was also evident. Based on observed audit firm concentration and audit firm rotation behaviour, it was anticipated that MAFR might further increase audit market concentration. A concerning result was the sheer scale of audit firm rotations to be carried out in anticipation of MAFR in 2023.

Practical implications: This study identified the impairment of audit quality and increased costs as possible unintended consequences of MAFR in South Africa.

Originality/value: This study contributed to the limited body of knowledge on the possible effect of MAFR in South Africa. This study proposed alternatives to MAFR and recommended areas for future research to support evidence-based decisions on remedies to address audit quality and audit market concentration in South Africa.

Keywords: audit market concentration; mandatory audit firm rotation; Big 4 audit firms; audit quality; audit firm tenure; emerging market; JSE.

\section{Introduction}

In response to the global financial crisis of 2007-2008, the audit profession has introduced tighter regulations, as has been the case after each successive crisis in the auditing or business sphere (Hay, 2015). Global regulatory responses have included the formulation of international auditing standards to improve audit quality, the expansion of audit reports, and country-specific regulations on limiting non-audit services and mandating audit firm rotations.

Mandatory audit firm rotation (MAFR) is a contentious topic that frequently resurfaces in debates on remedies to address audit quality. The differing views on MAFR are, however, evident when comparing the stance on audit rotation in the United States of America (USA) and the European Union (EU), with the USA deciding against implementation, whilst the EU implemented MAFR in 2016.

Audit firm tenure is central to the debates on MAFR. On the one hand, it is argued that longer audit firm tenure represents an increased likelihood of familiarity, even friendship and dependence on an audit client and therefore a likely lower-quality audit, whilst on the other hand, the view is held that longer audit firm tenure represents greater knowledge of a company's business and a higher-quality and more efficient audit (Corbella, Florio, Gotti, \& Mastrolia, 2015). The fact that the market for auditing in many countries is concentrated in a small number of suppliers - the so-called Big 4 audit firms, namely, PricewaterhouseCoopers (PwC), Deloitte, Ernst \& Young (EY) and Klynveld, Peat, Marwick, Goerdeler (KPMG) - have added to the debate on MAFR. It is argued that audit quality could be low in oligopolistic markets because of clients' lack of auditor choice and the limited degree of competition (Bleibtreu \& Stefani, 2018), as opposed to the view that audit market concentration is a natural and permanent global phenomenon, driven by 
economies of scale, a global footprint and prior mergers of audit firms (Velte \& Stiglbauer, 2012).

Jurisdictions introducing MAFR, therefore, generally argue that it is a measure that would strengthen independence and decrease audit market concentration, whilst non-adopters of MAFR stress the importance of auditors' learning curve and the effect thereof on audit quality and audit fees (Bleibtreu \& Stefani, 2018).

Empirical evidence on whether MAFR is an effective measure is, however, limited, mainly because there are so few countries where it has been enforced (Hay, 2015). Most research on audit firm rotation is conducted in jurisdictions where voluntary rotation is applicable, which may affect the reported results, as voluntary rotation is often in respect of troubled companies (e.g. companies that are susceptible to fraud, that are financially distressed or that are in disagreement with their auditor's opinion) (Casterella \& Johnston, 2013). Audit-related research is also mostly based on the experience of developed countries, with research from developing countries being scant (Hay, 2017).

South Africa is a developing country with a dual economy and shares characteristics with both developed and developing countries (Grant, Harber, \& Minter, 2018), providing a unique opportunity to add to the debate on MAFR. The country was ranked number one in the world for high auditing and reporting standards by the World Economic Forum for seven consecutive years (2010-2016), but has subsequently dropped to number 30, mainly in response to the decline in investor confidence in the country ('Drop in SA audit ranking no surprise', 2017). In an attempt to restore investor confidence, the South African Independent Regulatory Board for Auditors (IRBA) perceives its role as important to enhance the reputation of South Africa as an investment market and to increase economic growth in this country (IRBA, 2020).

On 05 June 2017, IRBA announced that MAFR will be effective in South Africa for all public interest entities for financial years commencing on or after 01 April 2023, with the objectives of enhancing auditor independence and to allow for accelerated transformation and deconcentration in the audit profession (IRBA, 2017a). In the motivation for MAFR, IRBA conceded that the period for which MAFR has been implemented in other jurisdictions, except for Italy, is too short to state empirically whether it is an effective measure. The stance of IRBA (2017c) was that research alone does not inform regulation and that empirical evidence is not required when investor protection is compromised. The present study aimed to address a gap in knowledge by conducting evidence-based research into one of the three stated focuses of MAFR in South Africa, namely, audit market concentration, for the eventual purpose of contributing to the development of policy in response to current issues.

This study contributes to literature on audit market concentration and audit firm tenure in a developing country with a dual economy. To the author's best knowledge, this is the first study to explore the expected effect of MAFR on audit market concentration in South Africa, based on observed trends in audit firm rotations and audit firm tenure. Insights obtained from this study can therefore inform stakeholders (including regulators) on whether additional measures are required to mitigate possible unintended consequences of MAFR prior to the implementation thereof in 2023.

The remainder of this article is structured as follows: Firstly, a literature review provides a background of global evidence of the relationship amongst audit quality, MAFR and audit concentration; a description of the audit concentration measures generally applied and a view of the South African regulatory environment pertaining to audit firm rotations. Thereafter, the methodology is described, followed by a discussion of the results. In the final section, the author draws a conclusion on the anticipated effect of MAFR on audit market concentration in South Africa, provides recommendations and sets out the limitations of the study and areas for future research.

\section{Literature review}

The enhancement of audit quality and auditor independence is at the heart of MAFR. Audit quality is difficult to define, with the International Auditing and Assurance Standards Board refraining from defining the concept, rather than providing a framework of factors that contribute to audit quality (Hay, 2015). A definition frequently applied in literature is that of DeAngelo (1981), stating that audit quality represents the joint probability that a given auditor will both discover a breach in a client's accounting system and report the breach. When evaluating the independence of an auditor, two dimensions of independence are considered, namely, independence of mind, ensuring that professional scepticism, professional judgement and the objectivity of the auditor remain unimpaired, and independence in appearance, referring to a reasonable third party's perception (IRBA, 2014).

\section{Mandatory audit firm rotation and audit quality}

A variety of approaches to and experiences with MAFR have been observed (Ewelt-Knauer, Gold, \& Pott, 2013). Some countries (e.g. Italy and Oman) have in the past implemented MAFR in all listed entities; others (e.g. Poland, Serbia, Slovenia and Peru) apply MAFR only in certain industries (e.g. insurance and governmental entities), whilst many countries have abolished MAFR after some time of practising it (e.g. Canada, Austria, Singapore, South Korea, Spain, Greece, Latvia and the Czech Republic) (Ewelt-Knauer et al., 2013; Lennox, 2014). Many countries have opted for audit partner, rather than audit firm, rotation (Ewelt-Knauer et al., 2013) and acknowledge the role of the audit committee (Park, 2019) in enhancing audit quality. From the top 20 countries ranked by the World Economic Forum, only six EU countries and China still apply MAFR (Harber, Marx, \& De Jager, 2020). 
The USA has mitigated auditor dependence concerns by passing the 2002 Sarbanes Oxley Act, which limits the amount and scope of non-audit services conducted by the auditor and requires audit partners to rotate every 5 years, whilst also requiring the disclosure of the name of the engaging audit partner as from 04 December 2013 (Tepalagul \& Lin, 2015). The USA did not adopt the MAFR rule, as it was perceived not to be the most cost-efficient way to strengthen independence (Bleibtreu \& Stefani, 2018). The future adoption of MAFR in the USA is considered unlikely (Fontaine, Khemakhem, \& Herda, 2017).

The EU, on the other hand, announced in May 2014 that MAFR would be applicable to public interest entities, effective from June 2016. Rotation after a maximum of 10 years (plus an additional 10 years if public tendering was conducted or an additional 14 years with respect to joint audits) would be required, with a cooling-off period of 4 years (Bleibtreu \& Stefani, 2018). Besides these prescripts, the EU applies restrictions on the amount and scope of non-audit services, whilst mandatory audit partner rotation (after five consecutive years) and the disclosure of the name of the engaging audit partner are also applicable (Francis, Michas, \& Seavey, 2013).

Evidence of the impact of MAFR on audit quality and auditor independence is inconclusive (Casterella \& Johnston, 2013; Ewelt-Knauer et al., 2013). There is some evidence that audit firm rotation may have a positive impact on 'independence in appearance', but evidence of the positive impact of audit firm rotation on 'independence in mind' is lacking and even in some instances reporting an adverse effect (Ewelt-Knauer et al., 2013). Cross-country studies on audit firm tenure have, in general, concluded that long tenure does not negatively affect audit quality (Garcia-Blandon, Argilés-Bosch, \& Ravenda, 2020a; Tepalagul \& Lin, 2015). The effect of audit firm tenure on audit quality was found to vary based on audit firm size: shorter tenure was associated with lower audit quality (Garcia-Blandon, Argilés-Bosch, \& Ravenda, 2020b), whilst Big 4 audit firms showed higher audit quality when compared to non-Big 4 audit firms (Riccardi, 2019).

Lennox (2014) and Casterella and Johnston (2013), however, cautioned that studies on the effect of MAFR on audit quality often have the shortcoming that, when based on voluntary (as opposed to mandatory) rotation data, the direction of the causality between audit firm tenure and audit quality is not easily determinable. These authors also question the suitability of 'abnormal accruals' (which are often used to measure earnings) as a measure of audit quality.

When reviewing results from studies using mandatory rotation data, studies from Italy (Cameran, Francis, Marra, \& Pettinicchio, 2015; Corbella et al., 2015), South Korea (Kwon, Lim, \& Simnett, 2014) and Spain (Harris \& Whisenant, 2012) showed mixed results. Lower earnings quality during the first 3 years following rotation was evident for Italian clients of the Big 4 audit firms during the period 2006-2009 (Cameran et al., 2015), whilst Corbella et al. (2015) reported increased audit quality in the first year of the new audit engagement for Italian clients of non-Big 4 audit firms (with no observed effect on audit quality for Big 4 audit firm clients) during the period 1998-2011. Harris and Whisenant (2012) reported an improvement in audit quality following the introduction of MAFR in South Korea and Spain, with Kwon et al. (2014) reporting an increase in audit fees in the Korean audit market over the total period of MAFR (2006-2010), without an observable positive effect on audit quality. In Italy, where MAFR has been applied since 1975, it was found that MAFR was costly, with abnormally high fees being charged subsequent to the initial engagement lowballing and abnormally higher fees being charged by the outgoing auditor (Cameran et al., 2015). In a study reviewing 24 academic studies on MAFR, Casterella and Johnston (2013), however, found that studies applying mandatory (as opposed to voluntary) rotation data do offer some support for MAFR.

Experiences from specific countries may, however, not be generalised to other countries owing to unique institutional features in these countries (e.g. the audit firm retention policy applicable in Italy and South Korea and the fact that Spain abolished MAFR before the first rotation was meant to occur) (Lennox, 2014). It is also recognised that the observed negative effect of MAFR in Italy (where approximately 30 audit firm rotations per annum are carried out) might be even greater in countries with larger audit markets and audit clients, such as the USA and other EU countries. It might, therefore, be difficult for larger audit markets to absorb the sheer number of audit rotations in an MAFR regime (Cameran et al., 2015).

Cognisance of differences in audit markets should therefore influence the interpretation of results of MAFR studies. Not only do regulatory environments pertaining to auditor independence (and audit quality) differ, but the results from studies based on voluntary rotations also cannot be generalised to an MAFR setting. A key policy question for countries applying audit partner rotation remains whether mandatory audit partner rotation is an effective substitute for MAFR (Lennox, 2014).

\section{Audit market concentration and audit quality}

Increased audit market concentration is a global phenomenon that has resulted from not only large audit firm consolidations in the late 1980s and 1990s but also the collapse of Arthur Andersen in 2001 and the exit of many small audit firms from the audit market for listed clients (because of tightening of regulations pertaining to listed entities) (Choi, Kim, Lee, \& Sunwoo, 2017). The Big 4 audit market concentration mainly arose in response to market forces, specifically the demand from investors for high-quality audits and the ability to undertake complex audits across the world (Malis \& Brozovic, 2015).

Regulators remain apprehensive that the dominance of a few large audit firms might diminish competition in the audit 
market and, hence, cause cartel pricing and a deterioration of audit quality (Choi et al., 2017). Investors, too, have raised concerns as to whether this level of concentration results in lower-quality audits and lower investment protection and they question whether financial markets could recover if one of the Big 4 audit firms failed or exited the market (Harris, 2017).

Audit market concentration is evident in most Western economies (Malis \& Brozovic, 2015). In a study covering 22 non-USA developed countries, Riccardi (2019) found that $67 \%$ of companies in Europe and Australia are audited by Big 4 audit firms. Based on market capitalisation, more than $90 \%$ of the EU and USA markets are audited by the Big 4 audit firms (Ottaway, 2013). France, where joint audits are mandatory, is the only big European economy where nonBig 4 audit firms have a sizeable market share (Malis \& Brozovic, 2015). Many fast-growing emerging economies have more open audit markets and reveal less Big 4 audit firm dominance (e.g. Big 4 audit firm concentration represents $41 \%$ in India and Croatia and only $14 \%$ in China), whilst Odesa and Agubata (2019) reported that $67 \%$ of the Nigerian market is audited by the Big 4 audit firms (mirroring the concentration evident in most developed economies).

Despite regulatory concerns, evidence is inconclusive on the association between audit market concentration and audit fees and quality (Choi et al., 2017). In a countrywide study of 42 countries for the period 1999-2007, Francis et al. (2013) found a positive association between audit quality and audit market concentration, whilst increased concentration within the Big 4 audit firm group was found to be negatively associated with audit quality. In another study (Choi et al., 2017) of 17 countries for the period 2004-2015, a significant positive association was found between audit market concentration and audit fees. However, this positive association was only evident in countries with a weaker regulatory environment and was more pronounced amongst clients of non-Big 4 audit firms (Choi et al., 2017). As concluded by Francis et al. (2013), the regulatory concern should therefore be the dominance of one or two Big 4 audit firms rather than a concentration of supply by the Big 4 audit group.

Although MAFR is proposed as a possible solution to reduce audit market concentration, empirical evidence indicates an increase rather than a decrease in audit market concentration in response to MAFR. A decrease in market competition (hence, an increase in audit market concentration) was experienced in South Korea in response to MAFR (Ewelt-Knauer, Gold, \& Pott, 2012), whilst Narayanaswamy and Raghunandan (2019) also found that MAFR is associated with higher audit market concentration in India. In anticipation of the implementation of MAFR in the EU, Bleibtreu and Stefani (2018) applied a static model to EU audit clients and concluded that regulators' goals of simultaneously addressing client importance and audit market concentration with MAFR are in direct conflict. A reduction in market concentration, but an increase in client dependence (hence, a decrease in audit quality), was foreseen for the post-MAFR EU audit market (Bleibtreu \& Stefani, 2018). Indyk (2019), however, reported an increase in the Big 4 audit firm concentration in Poland (which is the EU member state that applies the shortest allowed tenure, i.e. 5 years) subsequent to the implementation of MAFR. It is anticipated that the EU MAFR rule, combined with the strong limits on the provision of non-audit services to EU audit clients, may influence audit firms to end the audit engagement and retain the (generally more rewarding) nonaudit services of a client, consequently decreasing the number of audit firms competing for a client (and further increasing audit market concentration) (Garcia-Blandon et al., 2020a; Indyk, 2019).

\section{Audit market concentration measures}

The measures of audit market concentration mainly entail the concentration ratio (CR), the Herfindahl-Hirschman index, the Gini coefficient and the Lorenz curve (Malis \& Brozovic, 2015).

In an audit context, the $\mathrm{CR}$ measures the percentage of the entire reference amount that is allocated to the $n$ biggest audit firms. Concentration ratio 4 is most commonly reported and calculates the sum of the market share of the four largest audit firms (Malis \& Brozovic, 2015). The reference amount to calculate the CR can be based on various metrics, including number of clients, audit fees and market capitalisation. Because audit fees are not publicly disclosed in all jurisdictions, surrogates for audit fees include client revenues or client assets (Beattie, Goodacre, \& Fearnley, 2003). The number of clients as a reference amount for CR is regarded as insufficient and is generally applied as an auxiliary variable (Velte \& Stiglbauer, 2012).

With respect to the audit market concentration measures other than CR, the Herfindahl-Hirschman index represents the sum of the squares of the market shares of all market participants and the Gini coefficient summarises the inequality in the market, as derived from the Lorenz curve (Malis \& Brozovic, 2015). The Lorenz curve is, therefore, a relative measure that merely graphically represents the frequency distribution (Velte \& Stiglbauer, 2012).

Based on CRs, oligopoly (a state of limited competition) is deemed present when, at most, three audit firms have a market share exceeding $50 \%$ or at least five audit firms have a market share above $66.6 \%$ (Velte \& Stiglbauer, 2012). A monopoly position is assumed if one audit firm has more than a third of the market share (Velte \& Stiglbauer, 2012).

\section{South African audit firm rotation regulations}

Mandatory audit firm rotation, with a maximum allowed tenure of 10 years, will be applied to public interest entities 
for financial years commencing on or after 01 April 2023 (IRBA, 2017b). An audit firm of a public interest entity that has a tenure of 10 or more consecutive financial years before the financial year commencing on or after 01 April 2023 will, therefore, be required to rotate and will only be eligible for reappointment after a cooling-off period of 5 years. The only transitional provision is with respect to joint audits where, if both audit firms have a tenure in excess of 10 years at the effective date of MAFR, only one firm is required to rotate, whilst the other firm will be granted an additional 2 years before rotation is required. The MAFR rules of South Africa are perceived as more onerous than the EU MAFR rules (PwC, 2017).

In anticipation of MAFR, IRBA also required that, as for reporting periods ending on or after 31 December 2015, the audit firms of public interest entities disclose their tenure in the audit report of the entity (IRBA, 2015). In addition, as from 20 September 2017, the decision to rotate audit firms was more transparent, with all companies listed on the Johannesburg Stock Exchange (JSE) required to announce the termination or resignation of the auditor and the reason therefor via the Securities Exchange News Service (SENS) of the JSE by no later than the end of the business day following the decision to terminate or the receipt of the resignation (JSE, 2017).

Apart from the proposed MAFR in South Africa, mandatory audit partner rotation after 5 years and the disclosure of the name of the engaging audit partner - as in the EU - are also applicable in this country. There is, however, no strict requirement regarding the external auditor's non-audit service delivery in South Africa, apart from the Companies Act (Republic of South Africa [RSA], 2008) requirement pertaining to the responsibility of the audit committee to assess the independence of the external auditor and approve the nature and extent of non-audit services delivered before recommending the appointment of the auditor to shareholders. Since the adoption of the new Companies Act (RSA, 2008) in May 2011, disclosure of audit fees in the annual report is no longer a requirement in the South African regulatory environment.

The motivations for IRBA's introduction of MAFR in South Africa included the observed long audit firm tenure of JSElisted companies (i.e. 21 JSE-listed companies having an audit tenure in excess of 50 years and the lengthiest tenure being 114 years in 2016); the Big 4 audit firm dominance of the audit market (i.e. Big 4 audit firm clients representing more than $90 \%$ of the market capitalisation of JSE-listed companies that had South African engagement partners who signed off their audit reports and Big 4 audit firms collecting $94 \%$ of total audit fees spent by JSE-listed companies in 2016) and especially the recent business failures and poor performance on IRBA quality reviews (IRBA, 2017c).

Subsequent to the promulgation of IRBA's decision (in June 2017) to implement MAFR in South Africa, the debate was fuelled by the auditing irregularity exposure of one of South
Africa's Big 4 audit firms, KPMG, towards the end of 2017. This audit failure and possible elimination of a Big 4 audit firm raised the spectre of a serious market disruption. A spike in reported audit firm rotations followed, based on SENS announcements of audit firm rotations after 2017, but IRBA commented that it appears that the spike was only in part attributable to KPMG replacements, as companies disclosed the anticipated MAFR as the main reason for their rotation (Buthelezi, 2019).

Research on audit firm rotations, audit firm tenure and audit market concentration in the South African market is scant, mainly because data on audit firm identity and audit firm tenure are not available in any commercial financial database. Grant et al. (2018) identified 29 audit firm rotations when studying the effect of voluntary audit firm rotations on audit fees for JSE-listed companies for the period 2000-2010. Although the study was descriptive in nature, evidence of a fee discount in the first year of the new audit engagement, with some evidence of fee increases in the second year of the new engagement with respect to companies changing to nonBig 4 audit firms, was found. Studies on audit fees in the post-2010 period are, however, affected by audit fees no longer being publicly available as a consequence of the amended Companies Act (Grant et al., 2018).

In anticipation of MAFR in South Africa, Welch, Harber and Minter (2017) explored the annual report disclosure practices on audit firm tenure prior to the introduction of the audit tenure disclosure rule in December 2015, which was based on the premise that disclosure of audit firm tenure allows stakeholders to assess auditors' independence on whether shareholders should consider replacing them. It was found that only 15 of the top 100 JSE-listed companies disclosed audit firm tenure prior to December 2015; disclosure was provided mainly to adhere to regulatory requirements pertaining to companies' dual listing status (Welch et al., 2017). These researchers supported the introduction of the audit tenure rule by IRBA in December 2015 and reiterated that the disclosure of audit firm tenure in annual reports was an important mechanism to strengthen the auditor's 'independence in appearance'.

In response to the promulgation of the MAFR regime in June 2017, a survey study on stakeholder perceptions (with responses from auditors, chief executive officers and audit committee chairs of the top 100 JSE-listed companies collected between August 2017 and November 2017) was conducted to assess the possible effect of MAFR in South Africa with respect to the three focus areas of MAFR, namely audit quality (Harber \& Marx, 2020), black economic empowerment (i.e. transformation) and audit market concentration (Harber \& Marx, 2019), as well as the financial effect of MAFR (Harber et al., 2020). With respect to audit quality, respondents concurred that business failures in South Africa are not attributed to audit quality being compromised (but rather to auditor error) and that MAFR will impair audit quality (Harber et al., 2020). With respect to transformation and 
audit market concentration, respondents anticipated that MAFR will reduce audit firms' capacity to pursue transformation initiatives (owing to the additional costs that MAFR will impose on audit firms) and that MAFR will increase audit market concentration (Harber \& Marx, 2019). Findings on audit market concentration include the reluctance of audit committees and shareholders of large listed companies to appoint non-Big 4 audit firms as auditors, based on the lack of resources, skills, experience and international presence of non-Big 4 audit firms compared to Big 4 audit firms. Furthermore, specialisation in some sectors, where not even all Big 4 audit firms are equally experienced, would cause such sectors to have only one or two appointable audit firms (Harber \& Marx, 2019, 2020). Although Harber et al. (2020) reported an anticipated increase in audit costs (for audit firms) under an MAFR regime, the reluctance of audit committee chairs to allow the increase led to mixed results on the anticipated effect of MAFR on audit fees. The financial effect of MAFR on audit firms and their clients (i.e. mainly the cost relating to the tendering and appointment process and additional staff time spent on explaining the business to the incoming auditor) was, however, seen as substantial by all respondents (Harber et al., 2020). Harber et al. (2020) recommended that IRBA should withdraw the MAFR regulation before the effective date or initiate more engagement opportunities with audit industry participants to address their concerns prior to the implementation date.

The review of South African literature on audit firm rotations, audit firm tenure and audit market concentration, therefore, showed that studies mainly focused on earlier periods in which MAFR was not an envisaged regulation (Grant et al., 2018) or were based on surveys conducted in the year when the MAFR regime was promulgated (Harber et al., 2020; Harber \& Marx 2019, 2020) and mainly focused on the top 100 JSE-listed companies (Harber et al., 2020; Harber \& Marx 2019, 2020; Welch et al., 2017). The present study aimed to add to literature by assessing the actual audit firm landscape (based on disclosures on audit firm identity and audit firm tenure) over a period that incorporates the pre-promulgation and post-promulgation of MAFR and covering all size categories (i.e. top 40, medium, small and fledglings) of JSElisted companies. The disclosure of audit firm tenure (as from 2016) will be interpreted as a signal to stakeholders of the 'independence in appearance' of the audit firm to assess whether to replace the audit firm in anticipation of the MAFR regulation (Buthelezi, 2019; Welch et al., 2017).

Based on global and South African literature reviewed, the study, therefore, hypothesises that South African audit market concentration will increase subsequent to the implementation of MAFR. With Big 4 audit firms showing the same dominance in the South African audit market as in developed countries, it is expected that the global evidence (on increased audit market concentration subsequent to MAFR) will be mirrored in South Africa. This expectation is also supported by evidence of South African audit market stakeholders' perspectives (Harber et al., 2020; Harber \& Marx, 2019).

\section{Methodology Sample selection}

The sample for the study comprised all companies listed on the JSE for the period 2010-2018 that employed South African engagement partners to sign off their audit reports. The sample companies were public interest entities to which the disclosure of audit firm tenure (effective from financial years ending on or after 31 December 2015) was applicable and the MAFR rules (effective from financial years commencing on or after 01 April 2023) were to apply. Delisted companies were included to eliminate survivorship bias.

The names of all companies listed on the JSE for the period 2010-2018 were extracted from the IRESS Expert financial database and were compared with the Profile Stock Exchange Handbook of the JSE for completeness. Table 1 shows that a total of 508 companies were listed on the JSE for the period 2010-2018.

A total of 87 companies were identified as having non-South African engagement partners signing off their annual reports (owing to being registered outside South Africa and/or having a primary listing on a stock exchange other than the JSE) and were, therefore, excluded from the study sample. From the remaining 421 companies, there were five companies that appointed joint auditors during the entire target period. These five companies were excluded from the sample to ensure comparability when calculating audit firm tenure and audit firm rotation. One company had missing data on the CR variables and was excluded. The final study sample, therefore, comprised 415 companies, represented by 2703 company year observations.

\section{Data collection and data analysis}

Data on South African auditor firm identity and audit firm tenure are not available in any commercial financial database. Audit firm identities were, therefore, hand-collected from audit reports in the annual reports of each company per reporting period. Audit firm tenure disclosures were captured from audit reports in annual reports covering the financial years commencing on/after 31 December 2015. Most companies disclosed only audit firm tenure, in line with the disclosure rule of December 2015, as from their 2016 reporting periods. Annual reports were retrieved from the IRESS database (product: Library).

Audit market concentration was calculated by applying the $C R$, as this measure is the most reported concentration

TABLE 1: Number of sample companies researched

\begin{tabular}{lc}
\hline Description & Sample \\
\hline Total number of companies listed on the JSE & 508 \\
Less: Companies with non-South African engagement & -87 \\
partners & -5 \\
Less: Companies with joint auditors & -1 \\
Less: Companies with missing data & 415 \\
\hline Final number of sample companies used in this study &
\end{tabular}

JSE, Johannesburg Stock Exchange. 
measure based on its ease of calculation and understanding (Pong, 1999; Velte \& Stiglbauer, 2012). The CR4, CR5, CR6 and CR7 values were calculated per year for the period 2010-2018, representing the market share of the largest group of four, five, six and seven audit firms, respectively. The $C R$ values were calculated on the basis of three reference amounts, namely number of clients, total assets and market capitalisation. Audit fees could not be used, because all companies do not disclose their audit fees in the annual report, in line with the non-mandatory disclosure of audit fees in the South African regulatory environment. Total assets (including intangibles) and market capitalisation were retrieved from the IRESS Expert database.

The expected effect of MAFR on audit market concentration was mainly based on the observed audit firm rotation and audit firm tenure behaviour in the period subsequent to the introduction of the 2015 audit tenure rule, on the premise that this disclosure on 'perceived auditor independence' motivated audit firm rotations in anticipation of MAFR (Buthelezi, 2019; Welch et al., 2017).

Audit firm rotations were identified on the basis of a change in name of audit firms that signed off the audit report per reporting period. Audit firm changes because of audit firm mergers were not categorised as an audit firm rotation, in line with the tenure disclosure rule pertaining to a predecessor audit firm (IRBA, 2017b). Owing to the SENS announcements on change of auditors, effective from 20 September 2017, mainly relating to audits for the 2018 financial year (and subsequent years), these announcements were not used as the primary source to collect audit firm rotation data. The SENS announcements were, however, captured and compared with newly appointed auditors (as disclosed in the relevant audit report) to ensure completeness of data.

Audit firm rotations were divided into pre-2016 (2010-2015) and post-2015 (2016-2018) rotations, based on audit firm rotation category (i.e. Big 4 to Big 4 , non-Big 4 to non-Big 4 , Big 4 to non-Big 4 and non-Big 4 to Big 4), audit firm size (i.e. Big 4 and non-Big 4), company size (top 40, medium, small and fledgling) and audit firm tenure (short, medium and long). The company size classifications (top 40, medium, small and fledgling) were obtained from indices received from the JSE. Companies listed on the AltX (a JSE platform to develop emerging and entrepreneurial companies) (Hasenfuss, 2020) were included in the fledgling classification. Audit firm tenure was categorised as short (3 years or fewer), medium (4-8 years) and long ( 9 years or more), in line with the methodology applied in earlier research (Johnson, Khurana, \& Reynolds, 2002; Riccardi, 2019).

Significance testing entailed the application of generalised estimating equations (GEEs) and mixed model of analysis of variance (ANOVA) techniques to assess the changes in market concentration and the chi-square statistical test to assess the changes in audit firm rotation categories. A 5\% level of significance was applied.

\section{Results \\ Descriptive statistics}

The descriptive statistics of the sample data are displayed in Table 2. The number of JSE-listed companies (clients) varied between 272 and 325 companies per year during the period 2010-2018. Audit firm tenure, as disclosed in the period 2016-2018, was on average 17 years, with a median of 10 years in 2016 and 2018 and a median of 8 years in 2017. At least half of the companies, therefore, already had an audit tenure of 10 years in 2018 and needed to rotate their auditors before or at the effective date (in 2023) of MAFR. The maximum audit tenure was extremely high (at 116 years in 2018), but SENS announcements on audit firm rotations showed that this company had rotated its auditors after 2018. The large difference between the average (mean) and median values for the total assets and market capitalisation figures indicated that a few very large companies were included in the sample data, as became evident in the reported maximum values.

\section{Audit market concentration}

\section{Concentration ratio 4 to concentration ratio 7}

Table 3 displays the CRs per year for the Big 4 audit firms (CR4), the five largest firms (CR5), the six largest firms (CR6) and the seven largest firms (CR7). The Big 4 audit firms comprised PwC, Deloitte, EY and KPMG, whilst Grant Thornton, Mazars and Binder Dijker Otte \& Co. (BDO) were added when calculating CR5, CR6 and CR7, respectively.

The CR4 figures in Table 3 are comparable to CRs reported for most developed countries (Riccardi, 2019). In 2018, approximately $68 \%$ of clients were audited by Big 4 audit firms, with clients' assets and market capitalisation representing $95 \%$ and $96 \%$ of the total market, respectively.

When comparing the CR4 figures over time, the number of clients ratio showed an increasing trend during the more recent period (2018 compared to 2015), whilst the asset and market capitalisation ratios fluctuated between $93 \%$ and $97 \%$ over the period. Significance results (at the 5\% level of significance), based on the GEE test, showed that the number of Big 4 audit clients increased significantly in 2017 and that the number of Big 4 audit clients in 2017 and 2018 was significantly higher than the number of Big 4 audit clients in 2015.

The CR7 figure (which includes the Big 4, Grant Thornton, Mazars and BDO) indicated that seven audit firms audited nearly $92 \%$ of the number of South African clients in 2018. The CR5 figure (which includes the Big 4 and Grant Thornton), when based on market capitalisation, shows that 
TABLE 2: Descriptive statistics on audit firm tenure and client size.

\begin{tabular}{|c|c|c|c|c|c|c|c|c|c|}
\hline Variable & 2018 & 2017 & 2016 & 2015 & 2014 & 2013 & 2012 & 2011 & 2010 \\
\hline Number of clients & 272 & 277 & 278 & 272 & 278 & 289 & 306 & 318 & 325 \\
\hline \multicolumn{10}{|c|}{ Audit firm tenure (years) } \\
\hline Average & 17.00 & 17.60 & 17.56 & $n / a$ & $\mathrm{n} / \mathrm{a}$ & $\mathrm{n} / \mathrm{a}$ & $\mathrm{n} / \mathrm{a}$ & $\mathrm{n} / \mathrm{a}$ & $\mathrm{n} / \mathrm{a}$ \\
\hline Median & 10.00 & 8.00 & 10.00 & $\mathrm{n} / \mathrm{a}$ & $\mathrm{n} / \mathrm{a}$ & $\mathrm{n} / \mathrm{a}$ & $\mathrm{n} / \mathrm{a}$ & $\mathrm{n} / \mathrm{a}$ & $\mathrm{n} / \mathrm{a}$ \\
\hline Maximum & 116.00 & 115.00 & 114.00 & $\mathrm{n} / \mathrm{a}$ & $\mathrm{n} / \mathrm{a}$ & $\mathrm{n} / \mathrm{a}$ & $\mathrm{n} / \mathrm{a}$ & $\mathrm{n} / \mathrm{a}$ & $\mathrm{n} / \mathrm{a}$ \\
\hline Minimum & 1.00 & 1.00 & 1.00 & $\mathrm{n} / \mathrm{a}$ & $\mathrm{n} / \mathrm{a}$ & $\mathrm{n} / \mathrm{a}$ & $\mathrm{n} / \mathrm{a}$ & $\mathrm{n} / \mathrm{a}$ & $\mathrm{n} / \mathrm{a}$ \\
\hline \multicolumn{10}{|c|}{ Clients' total assets (ZAR'000) } \\
\hline Average & 27540106 & 24389217 & 22872653 & 21453906 & 17834829 & 15491400 & 12655517 & 10816275 & 11846305 \\
\hline Median & 5167422 & 3911666 & 3790000 & 3566858 & 2648010 & 2276200 & 1770315 & 1246322 & 1155396 \\
\hline Maximum & 815601000 & 733583000 & 672559000 & 674508000 & 611253000 & 561304000 & 443564000 & 382203000 & 845240000 \\
\hline Minimum & 93 & 311 & 1 & 2411 & 3362 & 8197 & 100 & 44 & 269 \\
\hline \multicolumn{10}{|c|}{ Clients' market capitalisation (ZAR'000 000) } \\
\hline Average & 18975918 & 21436466 & 16854777 & 16560105 & 15674631 & 13329677 & 11336772 & 9024076 & 8941750 \\
\hline Median & 2411474 & 2531230 & 2531917 & 2186165 & 2074707 & 1687857 & 1143935 & 868676 & 804499 \\
\hline Minimum & 876 & 76 & 4607 & 2673 & 2024 & 2062 & 203 & 2521 & 500 \\
\hline
\end{tabular}

ZAR, South African rand

TABLE 3: Concentration ratios of the South African audit market.

\begin{tabular}{|c|c|c|c|c|c|c|c|c|c|}
\hline Variable & $2018(\%)$ & $2017(\%)$ & $2016(\%)$ & $2015(\%)$ & $2014(\%)$ & $2013(\%)$ & $2012(\%)$ & $2011(\%)$ & $2010(\%)$ \\
\hline \multicolumn{10}{|l|}{ CR4 } \\
\hline Number of clients & 68.01 & 70.04 & 68.35 & 65.68 & 66.43 & 66.20 & 64.80 & 62.66 & 63.89 \\
\hline Total assets & 94.94 & 95.06 & 94.92 & 93.70 & 94.44 & 94.80 & 93.91 & 92.88 & 94.11 \\
\hline Market capitalisation & 96.10 & 96.72 & 95.16 & 93.96 & 94.10 & 94.54 & 94.93 & 95.20 & 94.98 \\
\hline \multicolumn{10}{|l|}{ CR5 } \\
\hline Number of clients & 79.12 & 84.42 & 82.67 & 80.44 & 78.70 & 77.00 & 70.72 & 68.99 & 69.44 \\
\hline Total assets & 98.00 & 98.60 & 98.43 & 98.63 & 98.60 & 98.63 & 96.14 & 95.61 & 96.18 \\
\hline Market capitalisation & 98.78 & 99.12 & 98.08 & 98.37 & 98.49 & 98.40 & 96.74 & 96.78 & 96.59 \\
\hline \multicolumn{10}{|l|}{ CR6 } \\
\hline Number of clients & 83.88 & 90.22 & 88.45 & 87.08 & 86.28 & 82.93 & 75.99 & 74.05 & 74.07 \\
\hline Total assets & 98.52 & 99.26 & 99.00 & 99.16 & 99.14 & 99.03 & 96.50 & 96.03 & 96.52 \\
\hline Market capitalisation & 99.04 & 99.52 & 98.89 & 99.09 & 99.13 & 98.88 & 96.98 & 97.12 & 96.91 \\
\hline \multicolumn{10}{|l|}{ CR7 } \\
\hline Number of clients & 91.58 & 93.48 & 92.06 & 91.14 & 90.61 & 87.46 & 81.58 & 80.06 & 78.70 \\
\hline Market capitalisation & 99.69 & 99.84 & 99.30 & 99.42 & 99.51 & 99.38 & 97.54 & 97.54 & 97.36 \\
\hline
\end{tabular}

$\mathrm{CR}$, concentration ratio.

five audit firms audited approximately 99\% of the audit market in 2018. The CR5 ratio in excess of $66.6 \%$ deemed oligopoly (Velte \& Stiglbauer, 2012) to be present in the South African audit market. When comparing the CR5 and CR7 figures based on the number of clients, the CR5 showed a larger decrease in 2018 when compared to the CR7. Generalised estimating equations results confirmed (at the 1\% level of significance) a significant decrease in the 2018 number of clients for Grant Thornton (identified as the fifthlargest audit firm in the analysis) and a significant increase in the 2018 number of audit clients of BDO (identified as the seventh-largest audit firm in the analysis). The South African merger of most of Grant Thornton's offices with those of BDO has, therefore, led to BDO becoming a larger mid-tier audit firm.

\section{Audit market concentration within concentration ratio 4}

Table 4 displays the market concentration within the Big 4 audit firm group. PricewaterhouseCoopers was the largest audit firm in the South African audit market. With a market share of $25 \%$ of audit clients and a share of $53 \%$ in the assets and market capitalisation of the market, $\mathrm{PwC}$ met the criteria of a monopoly position (Velte \& Stiglbauer, 2012) in the South African audit market. Its market share showed an increased trend over time and indicated that $\mathrm{PwC}$ might have been appointed to audit larger companies in recent years (2018 compared to 2015).

Deloitte is the second-largest audit firm in the Big 4 audit firm group. Although its number of clients ratio has increased since 2015, Deloitte's market share based on assets and market capitalisation decreased, which may indicate that the firm was appointed to audit smaller companies in recent years (2016-2018).

Although KPMG is ranked third based on the number of audit clients, its number of clients ratio showed a decreasing trend, as opposed to that of EY, which showed an increased trend over time (2010-2018). The audit failure of KPMG in 2017 resulted in some clients sourcing replacement auditors. Ernst \& Young, therefore, may well rank third in the years following 2018. Significance results, based on the GEE test, confirmed that the number of KPMG 
TABLE 4: Market share per Big 4 audit firm in the South African audit market.

\begin{tabular}{|c|c|c|c|c|c|c|c|c|c|}
\hline Variable & $2018(\%)$ & $2017(\%)$ & $2016(\%)$ & $2015(\%)$ & $2014(\%)$ & $2013(\%)$ & $2012(\%)$ & $2011(\%)$ & $2010(\%)$ \\
\hline \multicolumn{10}{|l|}{ PwC } \\
\hline Number of clients & 25.27 & 24.28 & 22.02 & 21.40 & 20.94 & 20.56 & 20.39 & 20.89 & 20.06 \\
\hline Total assets & 53.12 & 50.07 & 47.46 & 47.01 & 44.24 & 36.04 & 35.48 & 35.93 & 47.49 \\
\hline $\begin{array}{l}\text { Market } \\
\text { capitalisation }\end{array}$ & 59.89 & 59.20 & 54.89 & 59.48 & 54.42 & 39.91 & 34.99 & 31.56 & 31.94 \\
\hline \multicolumn{10}{|l|}{ Deloitte } \\
\hline Number of clients & 19.41 & 19.20 & 17.33 & 16.97 & 17.33 & 17.42 & 17.43 & 17.41 & 18.21 \\
\hline Total assets & 13.42 & 15.38 & 16.07 & 16.59 & 18.51 & 21.47 & 21.46 & 21.49 & 18.14 \\
\hline $\begin{array}{l}\text { Market } \\
\text { capitalisation }\end{array}$ & 12.33 & 13.34 & 14.60 & 13.24 & 16.51 & 24.79 & 27.35 & 29.32 & 30.81 \\
\hline \multicolumn{10}{|l|}{ KPMG } \\
\hline Number of clients & 12.09 & 15.58 & 17.69 & 16.97 & 18.41 & 19.16 & 19.08 & 18.04 & 19.75 \\
\hline Total assets & 9.06 & 10.88 & 11.90 & 10.03 & 10.10 & 15.22 & 15.46 & 15.38 & 12.98 \\
\hline $\begin{array}{l}\text { Market } \\
\text { capitalisation }\end{array}$ & 7.86 & 9.70 & 10.24 & 7.63 & 7.82 & 15.99 & 16.37 & 19.22 & 17.73 \\
\hline \multicolumn{10}{|l|}{ EY } \\
\hline Number of clients & 11.36 & 10.87 & 11.19 & 10.33 & 9.75 & 9.06 & 7.89 & 6.33 & 5.86 \\
\hline Total assets & 19.33 & 18.73 & 19.50 & 20.07 & 21.59 & 22.07 & 21.51 & 20.09 & 15.51 \\
\hline $\begin{array}{l}\text { Market } \\
\text { capitalisation }\end{array}$ & 16.53 & 14.48 & 15.44 & 13.62 & 15.35 & 13.85 & 16.22 & 15.10 & 14.50 \\
\hline
\end{tabular}

PwC, PricewaterhouseCoopers; KPMG, Klynveld, Peat, Marwick, Goerdeler; EY, Ernst \& Young.

clients decreased significantly (at the $5 \%$ level of significance) in 2018.

Securities Exchange News Service announcements on audit firm rotations in the post-2018 period indicate that a change in the South African Big 4 audit firm group occurred in 2019. Based on the number of clients, KPMG was replaced by EY as the third-largest audit firm, whilst BDO was ranked fourth and KPMG fifth in 2019. Whether this change in ranking will persist will need to be confirmed when analysing the published annual reports of 2019 and subsequent periods. Number of clients does not, however, necessarily denote the true market share; an analysis of assets and market capitalisation is required to confirm the market concentration of the post-2018 period. Securities Exchange News Service announcements on audit firm rotations in 2019 and 2020 do, however, indicate that clients are starting to re-appoint KPMG as their auditor and that the company is recovering from its reputational tumble.

The reported results on the concentration of the South African audit market, therefore, indicate a significant increase (based on the GEE test) in Big 4 audit clients after 2015. An increase (although not statistically significant in terms of the ANOVA tests) in CRs based on total assets and market capitalisation was also observed over time. Concentration ratios mirror global empirical evidence in respect of Big 4 audit firm dominance. Based on the premise that post-2015 audit firm rotations were motivated by the anticipated MAFR regime (Buthelezi, 2019; Welch et al., 2017), the post-2015 trends in CRs seem to support the expectation that MAFR may increase audit market concentration.

The reported results on the concentration of the South African audit market also point towards possible audit quality and financial market stability concerns. The negative association between concentration within the Big 4 audit firm group and audit quality (Francis et al., 2013) may be a reality (i.e. with respect to $\mathrm{PwC}$ ) that needs to be addressed in the South African audit market and investors' concerns over whether financial markets can recover from the failure, or exit, of one of the Big 4 audit firms (Harris, 2017) may not be unfounded (i.e. $\mathrm{KPMG).}$

\section{Comparing pre-2016 (2010-2015) and post-2015 (2016-2018) audit firm rotations}

Tables 5, 6 and 7 respectively show the audit firm rotations (per audit firm rotation category and client size) affected during the period (and distinguishes between the pre-2016 and post-2015 period); the audit firm tenure reported for the 2016-2018 period with respect to all clients included in the sample; and the audit firm tenure (per client size classification) for only the 2018 year.

Table 5 shows that a total of 141 audit firm rotations occurred during the period 2010-2018. As stated in the methodology section, these audit firm rotations exclude mergers between audit firms and joint auditor appointments. The 141 audit firm rotations were carried out by 117 companies. From Table 5, it is observed that the rotations per rotation category differ when comparing the pre-2016 and post-2015 periods. In the earlier period, non-Big 4 to non-Big 4 rotations (38) were the dominated rotation category (representing approximately $41 \%$ of all rotations), whereas Big 4 to Big 4 rotations (25) dominated the 2016-2018 period (representing approximately $51 \%$ of all rotations). A chi-square significance test showed (at the $1 \%$ level of significance) that the occurrence of Big 4 to Big 4 rotations increased significantly in the post-2015 period and the occurrence of non-Big 4 to non-Big 4 rotations decreased significantly in the post-2015 period. It is also evident that, in the post-2015 period, Big 4 audit clients (represented by 31 clients, namely 25 plus 6) mainly switched to other Big 4 audit firms (namely 25 or $81 \%$, of the 31 clients) and that non-Big 4 audit clients (represented 
TABLE 5: Audit firm rotations per audit firm size and client size.

\begin{tabular}{|c|c|c|c|c|c|c|c|c|c|c|c|c|c|c|}
\hline \multirow[t]{3}{*}{ Rotation category } & \multicolumn{6}{|c|}{ 2010-2015 } & \multicolumn{6}{|c|}{$2016-2018$} & \multirow{2}{*}{\multicolumn{2}{|c|}{$\begin{array}{c}\text { Total period } \\
\text { Number of clients }\end{array}$}} \\
\hline & \multicolumn{2}{|c|}{ Number of clients } & \multicolumn{4}{|c|}{ Client size } & \multicolumn{2}{|c|}{ Number of clients } & \multicolumn{4}{|c|}{ Client size } & & \\
\hline & $n$ & $\%$ & Top 40 & Medium & Small & Fldg & $n$ & $\%$ & Top 40 & Medium & Small & Fldg & $n$ & $\%$ \\
\hline Big 4 to Big 4 & 13 & 14.13 & 4 & 3 & 1 & 5 & 25 & 51.02 & 3 & 7 & 4 & 11 & 38 & 26.95 \\
\hline $\begin{array}{l}\text { Non-Big } 4 \text { to non- } \\
\text { Big } 4\end{array}$ & 38 & 41.30 & 0 & 0 & 4 & 34 & 7 & 14.29 & 0 & 0 & 0 & 7 & 45 & 31.92 \\
\hline Big 4 to non-Big 4 & 14 & 15.22 & 0 & 0 & 0 & 14 & 6 & 12.24 & 0 & 1 & 1 & 4 & 20 & 14.18 \\
\hline Non-Big 4 to Big 4 & 27 & 29.35 & 0 & 1 & 5 & 21 & 11 & 22.45 & 1 & 2 & 2 & 6 & 38 & 26.95 \\
\hline Total & 92 & 100.00 & 4 & 4 & 10 & 74 & 49 & 100.00 & 4 & 10 & 7 & 28 & 141 & 100.00 \\
\hline
\end{tabular}

Fldg, fledgling.

by 18 clients, namely 7 plus 11) mainly replaced their auditors with Big 4 audit firms (namely 11 or $61 \%$, of the 18 clients). About 74\% (or 36, namely 25 plus 11) of the 49 audit firm replacements that occurred in the post-2015 period were awarded to Big 4 audit firms. Based on client size, Table 5 also shows that, in the post-2015 period, larger companies (represented by the top 40 and medium classifications) mainly appointed Big 4 audit firms (with 13 or $93 \%$, of the 14 large company audit firm replacements being awarded to the Big 4) and that smaller companies (represented by the small and fledgling classifications) also preferred appointing Big 4 audit firms (with 23 or $66 \%$, of the 35 smaller company audit firm replacements being awarded to the Big 4). The results of the post-2015 period not only, therefore, support the findings of Harber and Marx (2019) that audit committees and shareholders are reluctant to appoint non-Big 4 audit firms for large listed companies, but also provide surprising evidence that Big 4 audit firms are also the preferred choice for smaller-size companies. An increase in audit market concentration is, therefore, expected based on the post-2015 audit firm rotation behaviour.

The replacement of KPMG with other auditors during the post-2017 period (when their reputational damage would have motivated the rotations) did not affect the chi-square significance results reported with respect to the post-2015 rotations. Eight KPMG replacements occurred in 2018, of which two were Big 4 to non-Big 4 rotations (within the smaller company size categories) and six were Big 4 to Big 4 rotations (within the medium and fledgling company size categories).

Table 6 shows the audit firm tenure landscape of the South African audit market with respect to Big 4 as opposed to nonBig 4 audit firms for the post-2015 period. Audit firm tenure per company was categorised as short (1-3 years), medium (4-8 years) and long (longer than 8 years).

From Table 6, it is evident that Big 4 audit firms were predominantly the auditors of clients with long audit firm tenure. The decreasing trend in the number of Big 4 audit firm clients with long audit tenures, combined with the increasing trend in the number of Big 4 audit firm clients with short audit tenures, supports the reported trends of Table 5, namely that post-2015 audit firm rotations were predominantly switches to Big 4 (and not non-Big 4) audit firms.
TABLE 6: Number of clients per audit firm tenure length and audit firm size (2016-2018).

\begin{tabular}{|c|c|c|c|c|c|c|c|c|c|}
\hline \multirow{2}{*}{$\begin{array}{l}\text { Tenure } \\
\text { length }\end{array}$} & \multicolumn{3}{|c|}{ Big 4} & \multicolumn{3}{|c|}{ Non-Big 4} & \multicolumn{3}{|c|}{ Total } \\
\hline & 2018 & 2017 & 2016 & 2018 & 2017 & 2016 & 2018 & 2017 & 2016 \\
\hline Short tenure & 49 & 40 & 31 & 17 & 21 & 24 & 66 & 61 & 55 \\
\hline $\begin{array}{l}\text { Medium } \\
\text { tenure }\end{array}$ & 18 & 29 & 32 & 36 & 27 & 36 & 54 & 56 & 68 \\
\hline Long tenure & 118 & 125 & 127 & 34 & 35 & 28 & 152 & 160 & 155 \\
\hline Total & 185 & 194 & 190 & 87 & 83 & 88 & 272 & 277 & 278 \\
\hline $\begin{array}{l}\text { Total per } \\
\text { year }(\%)\end{array}$ & 68.01 & 70.04 & 68.35 & 31.99 & 29.96 & 31.65 & 100.00 & 100.00 & 100.00 \\
\hline
\end{tabular}

Table 7 (where only the 2018 audit firm tenures are reported) shows that approximately 206 audit firm replacements (namely with respect to 54 medium-tenure and 152 long-tenure clients) need to be carried out subsequent to the 2018 reporting period in anticipation of the 2023 MAFR rule of a maximum tenure of 10 years. Most of these post-2018 rotations (approximately 66\%, represented by 18 medium-tenure clients and 118 longtenure clients) will involve the replacement of a Big 4 audit firm and relate to all client size categories. Based on the post-2015 audit firm rotation trends observed in Tables 5 and 6, these post-2018 Big 4 audit firm replacements will most probably be awarded to other Big 4 audit firms. Post2018 rotations to be affected in the non-Big 4 category mostly relate to smaller-size companies (Table 7), but, as was observed in the post-2015 period in Table 5, smaller companies do not necessarily appoint non-Big 4 audit firms nor do they necessarily switch from a non-Big 4 to another non-Big 4 audit firm. Based on the observed audit firm rotation behaviour in the post-2015 period (Tables 5 and 6) and the premise that post-2015 audit firm rotations were motivated by the anticipated MAFR regime (Buthelezi, 2019; Welch et al., 2017), the audit firm tenure landscape observed in 2018 (Table 7), therefore, supports the expectation of this study, namely that increased audit market concentration is expected in an MAFR regime.

The sheer number of audit firm rotations to be carried out in the 4 years (2019-2022) until the effective date of MAFR (in 2023) raises the question of whether Big 4 audit firms (and the South African audit market) have the capacity to accommodate these rotations - and what the effect on audit quality will be owing to multiple new audit engagements to be undertaken. With many Big 4 audit firms already providing additional non-audit services to companies required to rotate, the options for new Big 4 audit firm appointments may be limited. The large market share of 
TABLE 7: Number of clients per audit firm tenure length, audit firm size and client size (2018).

\begin{tabular}{|c|c|c|c|c|c|c|c|c|c|c|c|c|c|c|c|}
\hline \multirow[t]{3}{*}{ Tenure length } & \multicolumn{5}{|c|}{ Big 4} & \multicolumn{5}{|c|}{ Non-Big 4} & \multicolumn{5}{|c|}{ Total } \\
\hline & \multirow{2}{*}{$\begin{array}{c}\text { Number } \\
\text { of clients } \\
2018\end{array}$} & \multicolumn{4}{|c|}{ Client size } & \multirow{2}{*}{$\begin{array}{c}\text { Number } \\
\text { of clients } \\
2018\end{array}$} & \multicolumn{4}{|c|}{ Client size } & \multirow{2}{*}{$\begin{array}{c}\text { Number } \\
\text { of clients } \\
2018\end{array}$} & \multicolumn{4}{|c|}{ Client size } \\
\hline & & Top 40 & Medium & Small & Fldg & & Top 40 & Medium & Small & Fldg & & Top 40 & Medium & Small & Fldg \\
\hline Short tenure & 49 & 5 & 10 & 11 & 23 & 17 & 0 & 0 & 2 & 15 & 66 & 5 & 10 & 13 & 38 \\
\hline Medium tenure & 18 & 3 & 5 & 3 & 7 & 36 & 0 & 0 & 8 & 28 & 54 & 3 & 5 & 11 & 35 \\
\hline Long tenure & 118 & 16 & 32 & 37 & 33 & 34 & 0 & 3 & 4 & 27 & 152 & 16 & 35 & 41 & 60 \\
\hline Total & 185 & 24 & 47 & 51 & 63 & 87 & 0 & 3 & 14 & 70 & 272 & 24 & 50 & 65 & 133 \\
\hline
\end{tabular}

Fldg, fledgling.

PwC may affect its ability to accommodate audit switches, whilst the reputational risk attached to dealing with KPMG may negatively affect its appointment as a replacement auditor. Evidence from the MAFR experience in the Italian audit market (Cameran et al., 2015) as well as stakeholders' perceptions of the South African audit market (Harber et al., 2020) has also indicated that it may be difficult for the South African audit market to absorb the cost associated with the scale of audit rotations to be carried out and that an impairment in audit quality is expected under an MAFR regime.

\section{Conclusion}

In June 2017, IRBA in South Africa announced that MAFR would be applicable to public interest entities for financial years commencing on or after 01 April 2023. The objectives of MAFR were explained as the enhancement of auditor independence and the promotion of accelerated transformation and deconcentration in the audit profession. Additional regulatory reform imposed to address auditor independence included the requirement to disclose audit firm tenure (effective from financial years commencing on or after 31 December 2015) and to report transparently on the decision to rotate auditors (effective from 20 September 2017).

With information on South African audit firm tenure only recently becoming available, this study aimed to assess the possible effect of MAFR on one of the stated objectives of MAFR, namely the deconcentration of the audit profession. Data on audit firm identity and audit firm tenure of companies listed on the JSE are not available in any commercial financial database and the present study is the first to apply empirical evidence to provide insights into audit market concentration, audit firm tenure and the audit rotation landscape in South Africa.

This study was based on a sample of 415 companies listed on the JSE over the period 2010-2018, covering 2703 company year observations. It was found that CRs in South Africa mirror global empirical evidence of most developed economies with respect to the dominance of the Big 4 audit firms. Within the Big 4 audit firm group, one audit firm, PwC, was found to have a monopoly in the audit market, whilst a change in the Big 4 constituents after 2018 was observed, with one Big 4 audit firm, KPMG, dropping to fifth place.
On the premise that the required disclosure of audit firm tenure (effective from December 2015) has motivated audit firm rotations in anticipation of MAFR, empirical evidence from the post-2015 period indicated a significant increase in the number of Big 4 audit clients, that audit firm rotations were predominantly awarded to Big 4 audit firms and that most of the audit firm replacements to be carried out after 2018 are with respect to Big 4 audit firms. Indications are, therefore, that MAFR may further increase Big 4 audit firm concentration in South Africa.

A cause for concern is the finding that an excessively large number of audit firm rotations need to be carried out prior to the implementation of MAFR in 2023. Based on the Big 4 dominance and sheer scale of audit firm rotations to be affected, this study identified an impairment of audit quality and an increase in costs as possible unintended consequences of MAFR in the South African audit market. A monopoly within the South African audit market, the risk of an audit failure of one of the Big 4 audit firms and the struggling South African economy add to the complexity and associated risks of MAFR in this country.

This study, therefore, concludes that South African MAFR rules might not attain the envisaged deconcentration objective. Regulators are urged to reconsider the implementation of MAFR or, alternatively, to implement additional measures to mitigate the unintended consequences of MAFR in South Africa prior to the implementation thereof in 2023.

As an alternative to MAFR, this study recommends that current South African auditor independence measures are rather strengthened and formalised, for example, strengthening the role of the audit committee and improving the audit peer review processes by IRBA and within audit firms. It is also recommended that the transformation and audit market concentration concerns within the South African audit market are rather addressed by considering the total audit market (and not focusing only on JSE-listed companies) to provide opportunities to small and mediumsize audit firms as well as to promote the consolidation of smaller audit firms into larger mid-tier audit firms (a development that is already evident as of late). However, if IRBA decides to proceed with the implementation of MAFR in 2023, it is advised that a staggered approach is implemented by initially only applying MAFR to certain sectors or only to joint audit engagements. 
The main limitation of this study is that voluntary rotation data were applied to explore the possible effect of MAFR on audit concentration in South Africa and that not all post-2015 rotations might have been carried out in anticipation of MAFR.

Avenues for future research related to South African MAFR include studies to assess the role of the audit committee and audit partner rotation as measures in enhancing audit quality and ascertaining the cost implications of audit rotations. Regulators are urged to reinstate the mandatory disclosure of audit fees in South Africa to allow researchers to provide insights into the costs associated with audit rotations and the effect thereof on audit quality.

\section{Acknowledgements Competing interests}

The author declares that there are no financial or personal relationships that may have inappropriately influenced the writing of the article.

\section{Author's contributions}

I declare that I am the sole author of this research article.

\section{Ethical considerations}

This article followed all ethical standards for research without direct contact with human or animal subjects.

\section{Funding information}

This research received no specific grant from any funding agency in the public, commercial or not-for-profit sectors.

\section{Data availability}

The data that support the findings of this study are available from the author upon reasonable request.

\section{Disclaimer}

The views and opinions expressed in this article are those of the author and do not necessarily reflect the official policy or position of any affiliated agency of the author.

\section{References}

Beattie, V., Goodacre, A., \& Fearnley, S. (2003). And then there were four: A study of UK audit market concentration - Causes, consequences and the scope for market adjustment. Journal of Financial Regulation and Compliance, 11(3), 250-265. https://doi.org/10.1108/13581980310810561

Bleibtreu, C., \& Stefani, U. (2018). The effects of mandatory audit firm rotation on client importance and audit industry concentration. The Accounting Review, 93(1), 1-27. https://doi.org/10.2308/accr-51728

Buthelezi, L. (2019). Spike in JSE-listed firms that rotate auditors. Business Day Retrieved from https://www.businesslive.co.za/bd/companies/financial-services/ 2019-04-01-spike-in-jse-listed-firms-rotating-auditors/

Cameran, M., Francis, J.R., Marra, A., \& Pettinicchio, A. (2015). Are there adverse consequences of mandatory auditor rotation? Evidence from the Italian experience. Auditing: A Journal of Practice and Theory, 3(2), 1-38. https://doi. org/10.2308/ajpt-50663

Casterella, J.R., \& Johnston, D. (2013). Can the academic literature contribute to the debate over mandatory audit firm rotation? Research in Accounting Regulation, 25(1), 108-116. https://doi.org/10.1016/j.racreg.2012.11.004
Choi, J.-H., Kim, J.-B., Lee, E.Y., \& Sunwoo, H.-Y. (2017). Audit market concentration and audit fees: An International investigation. SSRN. Retrieved from https://www. researchgate.net/publication/317798459_Audit_Market_Concentration_and researchgate.net/publication/_Fees_An_International_Investigation

Corbella, S., Florio, C., Gotti, G., \& Mastrolia, S.A. (2015). Audit firm rotation, audit fees and audit quality: The experience of Italian public companies. Journal of International Accounting, Auditing and Taxation, 25, 46-66. https://doi. International Accounting, Auditing and
org/10.1016/j.intaccaudtax.2015.10.003

DeAngelo, L.E. (1981). Auditor size and audit quality. Journal of Accounting and Economics, 3(3), 183-199. https://doi.org/10.1016/0165-4101(81)90002-1

Drop in SA audit ranking no surprise. (2017). Accounting Weekly. Retrieved from https://accountingweekly.com/drop-sa-audit-ranking-no-surprise/

Ewelt-Knauer, C., Gold, A., \& Pott, C. (2012). What do we know about mandatory audit firm rotation? Amsterdam: Vrije Universiteit. Retrieved from https://research. vu.nl/en/publications/what-do-we-know-about-mandatory-audit-firm-rotation

Ewelt-Knauer, C., Gold, A., \& Pott, C. (2013). Mandatory audit firm rotation: A review of stakeholder perspectives and prior research. Accounting in Europe, 10(1), 27-41. https://doi.org/10.1080/17449480.2013.772717

Fontaine, R., Khemakhem, H., \& Herda, D.N. (2017). Why audit committees oppose mandatory audit firm rotation: Interview evidence from Canada. Current Issues in Auditing, 11(1), 11-15. https://doi.org/10.2308/ciia-51650

Francis, J.R., Michas, P.N., \& Seavey, S.E. (2013). Does audit market concentration harm the quality of audited earnings? Evidence from audit markets in 42 countries. Contemporary Accounting Research, 30(1), 325-355. https://doi. countries. Contemporary Accounting
org/10.1111/j.1911-3846.2012.01156.x

Garcia-Blandon, J., Argilés-Bosch, J.M., \& Ravenda, D. (2020a). Audit firm tenure and audit quality: A cross-European study. Journal of International Financial Management and Accounting, 31(1), 35-64. https://doi.org/10.1111/ Management
jifm.12098

Garcia-Blandon, J., Argilés-Bosch, J.M., \& Ravenda, D. (2020b). On the relationship between audit tenure and fees paid to the audit firm and audit quality. Accounting in Europe, 17(1), 78-103. https://doi.org/10.1080/17449480.2019.1669808

Grant, R., Harber, M., \& Minter, T. (2018). An analysis of the impact of audit firm rotation on audit fees: A South African perspective. African Journal of Accounting, Auditing and Finance, 6(2), 91-108. https://doi.org/10.1504/ AJAAF.2018.092361

Harber, M., \& Marx, B. (2019). An analysis of the possible impact of mandatory audit firm rotation on the transformation and market concentration of the South African audit industry. Journal of Economic and Financial Sciences, 12(1), 1-14. https://doi.org/10.4102/jef.v12i1.227

Harber, M., \& Marx, B. (2020). Audit quality and independence concerns in the South African audit industry: Contrasting views. South African Journal of Accounting Research, 34(1), 1-23. https://doi.org/10.1080/10291954.2019.1667646

Harber, M., Marx, B., \& De Jager, P. (2020). The perceived financial effects of mandatory audit firm rotation. Journal of International Financial Management and Accounting, 31(2), 216-234. https://doi.org/10.1111/jifm.12115

Harris, K., \& Whisenant, S. (2012). Mandatory audit rotation: An International investigation. Retrieved from http://citeseerx.ist.psu.edu/viewdoc/download?do $\mathrm{i}=10.1 \cdot 1.470 .1002 \& \mathrm{rep}=\mathrm{rep} 1 \&$ type $=\mathrm{pdf}$

Harris, S.B. (2017). Audit industry concentration and potential implications. Speech delivered at the 2017 International Institute meeting on auditing regulation 07 December, Washington, DC. Retrieved from https://pcaobus.org/News/ Speech/Pages/Harris-Audit-Industry-Concentration-12-07-17.aspx

Hasenfuss, M. (2020). AltX: The alternative exchange. Businesslive. Retrieved from https://www.businesslive.co.za/fm/features/cover-story/2020-01-09-altx-thealternative-exchange/

Hay, D. (2015). The frontiers of auditing research. Meditari Accountancy Research, 23(2), 158-174. https://doi.org/10.1108/MEDAR-12-2014-0062

Hay, D. (2017). Opportunities for auditing research: Back to our interdisciplinary roots Meditari Accountancy Research, 25(3), 336-350. https://doi.org/10.1108/ MEDAR-04-2017-0137

Independent Regulatory Board for Auditors (IRBA). (2014). Code of professiona conduct. Retrieved from https://www.irba.co.za/upload/16\%20IRBA $\% 20$ Code $\% 20$ of $\% 2$ Professional $\% 20$ Conduct $\% 20-\% 20$ ED $\% 2$ Final $\% 2020 \% 20$ November\%202009.pdf

Independent Regulatory Board for Auditors (IRBA). (2015). Strengthening auditor independence by making disclosure of audit tenure mandatory. Retrieved from https://www.gov.za/sites/default/files/gcis_document/201512/39475bn138. pdf

Independent Regulatory Board for Auditors (IRBA). (2017a). MAFR gazetted to enhance auditor independence and protect public interest. Retrieved from https://www. saica.co.za/Technical/Assurance/Latestdevelopmentsintheauditingprofession/ MandatoryAuditFirmRotation/MAFRgazettedtoenhanceauditorindependenceand/ tabid/4109/language/en-ZA/Default.aspx

Independent Regulatory Board for Auditors (IRBA). (2017b). Rule on mandatory audit firm rotation. Retrieved from https://www.irba.co.za/upload/Government $\% 20$ Gazette\%20with\%20Final\%20Rule\%20-\%201\%20June\%202017.pdf

Independent Regulatory Board for Auditors (IRBA). (2017c). Strengthening auditor independence to enhance public investor protection through mandatory audit firm rotation (MAFR): Frequently asked questions. Retrieved from https://www. irba.co.za/upload/FAQMAFR 2017.pdf

Independent Regulatory Board for Auditors (IRBA). (2020). Court rules on disclosure of documents in MAFR challenge. Retrieved from https://www.irba.co.za/newsheadlines/press-releases/court-rules-on-disclosure-of-documents-in-mafrchallenge 
Indyk, M. (2019). Mandatory audit rotation and audit market concentration: Evidence from Poland. Economics and Business Review, 5(4), 90-111. https://doi. org/10.18559/ebr.2019.4.5

Johannesburg Stock Exchange (JSE). (2017). JSE listings requirements: Service issue no. 25. Johannesburg: LexisNexis Butterworths.

Johnson, V.E., Khurana, I.K., \& Reynolds, J.K. (2002). Audit-firm tenure and the quality of financial reports. Contemporary Accounting Research, 19(4), 637-660. https:// doi.org/10.1506/LLTH-JXQV-8CEW-8MXD

Kwon, S.Y., Lim, Y., \& Simnett, R. (2014). The effect of mandatory audit firm rotation on audit quality and audit fees: Empirical evidence from the Korean audit market. Auditing: A Journal of Practice and Theory, 33(4), 167-195. https://doi. org/10.2308/ajpt-50814

Lennox, C. (2014). Auditor tenure and rotation. In D. Hay, W.R. Kneche, \& M. Willeken (Eds.), The Routledge companion to auditing (pp. 89-106). London: Routledge.

Malis, S.S., \& Brozovic, M. (2015). Audit market concentration: Evidence from Croatia. Ekonomski Vjesnik, 28(2), 339-356.

Narayanaswamy, R., \& Raghunandan, K. (2019). The effect of mandatory audit firm rotation on audit quality, audit fees and audit market concentration: Evidence from India. IIM Bangalore Research Paper no. 582. Retrieved from https://papers. ssrn.com/sol3/papers.cfm?abstract_id=3360256

Odesa, J., \& Agubata, N.S. (2019). Audit selection regime and audit marke concentration in a diversified economy: Evidence from Nigeria. Asian Journal of Science and Technology, 10(4), 9633-9638.

Ottaway, J. (2013). Improving auditor independence in Australia: Is 'mandatory audit firm rotation' the best option? Melbourne: University of Melbourne. Retrieved from http://law.unimelb.edu.au/_data/assets/pdf file/0004/170 9509/27-OTTAWAYJoanne-MandatoryAuditFirmRotationPaper2.pdf
Park, B-J. (2019). Audit committee compensation, best practices and audit fees. South African Journal of Business Management, 50(1), a1293. https://doi.org/10.4102/ sajbm.v50i1.1293

Pong, C.K.M. (1999). Auditor concentration: A replication and extension for the UK audit market 1991-1995. Journal of Business Finance and Accounting, 26(3/4) 451-475. https://doi.org/10.1111/1468-5957.00263

PricewaterhouseCoopers (PwC). (2017). Understanding mandatory audit firm rotation in South Africa. Retrieved from https://www.pwc.co.za/en/assets/pdf/ understanding-mafr.pdf

Republic of South Africa (RSA). (2008). Companies Act, No. 71 of 2008. Pretoria: Government Printer.

Riccardi, W.N. (2019). Do audit firm tenure and size moderate changes in financial reporting quality due to mandatory IFRS adoption? Auditing: A Journal of Practice and Theory, 38(4), 201-224. https://doi.org/10.2308/ajpt-52406

Tepalagul, N., \& Lin, L. (2015). Auditor independence and audit quality: A literature review. Journal of Accounting, Auditing and Finance, 30(1), 101-121. https://doi. org/10.1177/0148558X14544505

Velte, P., \& Stiglbauer, M. (2012). Audit market concentration and its influence on audit quality. International Business Research, 5(11), 146-161. https://doi. org/10.5539/ibr.v5n11p146

Welch, K.-A.O., Harber, M., \& Minter, T. (2017). An analysis of audit firm tenure disclosure in JSE listed companies by those charged with governance. Southern African Accounting Association Biennial International Conference Proceedings (pp. 9-29). Retrieved from http://www.saaa.org.za/Downloads/Publications/ AUD 004\%20An\%20Analysis $\% 20$ of $\% 20$ Audit $\% 20$ Firm $\% 20$ Tenure $\% 20$ Disclosure $\% 20$ in $\% 20 J S E \% 20$ Listed $\% 20$ Companies.pdf 